JPE 11-3-14

\title{
DC Micro-Grid Operational Analysis with a Detailed Simulation Model for Distributed Generation
}

\author{
Ji-Heon Lee*, Hyun-Jun Kim*, Byung-Moon Han ${ }^{\dagger}$, Yu-Seok Jeong*, Hyo-Sik Yang**, and Han-Ju Cha*** \\ $\dagger^{*}$ Dept. of Electrical Engineering, Myongji University, Yongin, Korea \\ ** Dept. of Computer Science and Engineering, Sejong University, Seoul, Korea \\ *** Dept. of Electrical Engineering, Chungnam National University, Daejeon, Korea
}

\begin{abstract}
This paper describes the operational analysis results of a DC micro-grid using a detailed model of distributed generation. A detailed model of wind power generation, photo-voltaic generation and fuel cell generation was implemented with an userdefined model created with PSCAD/EMTDC software and coded in C-language. The operational analysis was carried out using PSCAD/EMTDC software, in which the power circuit is implemented by a built-in model and the controller is modeled by an user-defined model that is also coded in C-language. Various simulation results confirm that a DC micro-grid can operate without any problems in both the grid-tied mode and in the islanded mode. The operational analysis results confirm that the DC micro-grid makes it feasible to provide power to the load stably. It can also be utilized to develop an actual system design.
\end{abstract}

Key Words: DC Distribution, DC Micro-grid, Distributed generation, Energy Management, Energy Storage, Fuel Cell Generation, Photo-Voltaic Generation, Wind Power Generation

\section{INTRODUCTION}

Recently, there has been a great deal of interest in smallscaled grid systems based on photovoltaic power generation and wind power generation in the fifty to ninety kilowatt range. Such a grid system, which is called as micro-grid, has advantages such as increases in operational efficiency and economics when it is connected to a grid or when used to supply secure electric power to islands, mountains and remote areas without a connecting grid [1]-[3]. The micro-grids are divided into AC micro-grids and DC micro-grids, depending on whether the DGs (distributed generations) and loads are connected on the basis of an AC or DC grid. AC micro-grids have the benefit of utilizing existing $\mathrm{AC}$ grid technologies, protections and standards, but synchronization, stability, and the need for reactive power are inherent demerits [4], [5].

On the other hand, DC micro-grids do not have the demerits of AC micro-grids. They also satisfy the demands of today since most environment-friendly DGs, such as photovoltaic, fuel cells and variable speed wind power systems, generate DC power and most digital loads require DC power. In addition, DC micro-grids can eliminate the DC-AC or AC-

\footnotetext{
Manuscript received Oct. 8, 2010; revised Mar. 21, 2011

Recommended for publication by Associate Editor Woo-Jin Choi.

$\dagger$ Corresponding Author: erichan@mju.ac.kr

Tel: +82-31-335-6563, Fax: +82-31-330-6816, Myongi University

* Dept. of Electrical Engineering, Myongji University, Korea

** Dept. of Computer Science and Engineering, Sejong University, Korea

*** Dept. of Electrical Engineering, Chungnam National University, Korea
}

DC power conversion stages required in AC micro-grids for the above renewable energy sources and loads. Therefore, they have advantages in terms of efficiency, cost and system size. However, DC micro-grids need further research on the proper operating range of DC voltage and protection apparatus for DC circuits [6], [7].

In this paper, detailed models of DGs are developed with the user-defined models of PSCAD/EMTDC software. A DC micro-grid is proposed by combining these models together with their relevant controllers. Grid-tied operation and standalone operation are verified through the proposed scenariobased energy management system.

\section{DC Micro-Grid CONFIGURATION}

As shown in Fig. 1, the proposed DC micro-grid consists of uncontrolled DGs such as wind power, photovoltaic generation and controlled fuel-cell sources as well as energy storage elements such as super-capacitors and batteries, DC loads and grid-tied converters.

The wind power system consists of a $2 \mathrm{~kW}$ PMSG (permanent magnet synchronous generator) which operates under a wide range of wind-speeds without a gear box, and a three-phase PWM converter which converts variable voltage, variable frequency AC voltage to fixed DC voltage with MPPT (maximum power point tracking) capability [8].

The PV (Photo-Voltaic) array converter is a $1.5 \mathrm{~kW}$ transformer-less boost converter which operates with the 


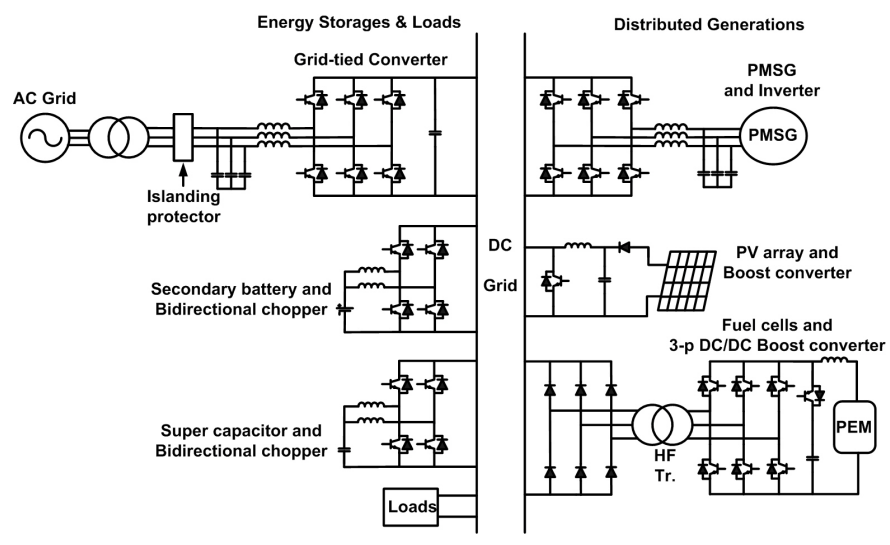

Fig. 1. Configuration of DC micro-grid.

MPPT method under varying levels of irradiation and temperature.

Since a $1.2 \mathrm{~kW}$ PEM (proton exchange membrane) type fuel cell stack generates a low varying DC voltage that is around $26 \mathrm{~V}$ and is strongly influenced by ripple current, a three-phase isolated DC-DC converter with an active clamp is employed to limit the ripple current into the fuel cells and to increase efficiency [9]. Bidirectional two-phase interleaved converters are used to charge or discharge into the elements. Energy storage elements such as super-capacitors and batteries play an important role for the power management of DC microgrids. They ensure a secure grid network and provide high quality power. A grid-tied three-phase converter, which is a conventional three-phase PWM converter, maintains a constant common DC grid voltage and regulates both the reactive power and the harmonic components in PCC. The DC load is simplified as a variable resistor in this paper [10].

\section{ANALYSIS OF THE PROPOSED DC MICRO-GRID}

\section{A. Power Flow}

The power flow of the components in the proposed DC micro-grid is shown in Fig. 2. The sum of the output power of the photovoltaic array, the wind power generator and the fuel cells is defined as $P_{D G}$ in (1).

$$
P_{D G}=P_{W G}+P_{P V}+P_{F C} .
$$

The DGs supply unidirectional power to the DC micro-grid and play a role as the main energy source. Since energy storage elements control the power balance of a DC micro-grid by charge and discharge, the power flow is bidirectional and the reference power for the elements is in (2). When the energy storage elements reach the state of full charge or discharge, the excessive power is supplied to or obtained from the AC grid, as shown in (3). The load demands unidirectional power from the micro-grid. According to a varying load demand, the energy storage element realizes a power balance, and thus it makes a continuous high-quality power supply to the load possible.

$$
\begin{gathered}
P_{E S}=P_{D G}-P_{L O A D} \\
P_{B U L K}=P_{D G}-P_{E S}-P_{L O A D} .
\end{gathered}
$$

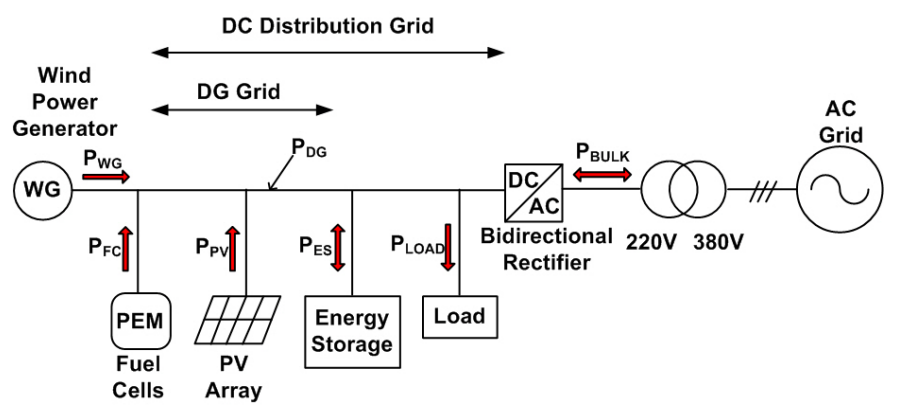

Fig. 2. Power flow of each component.
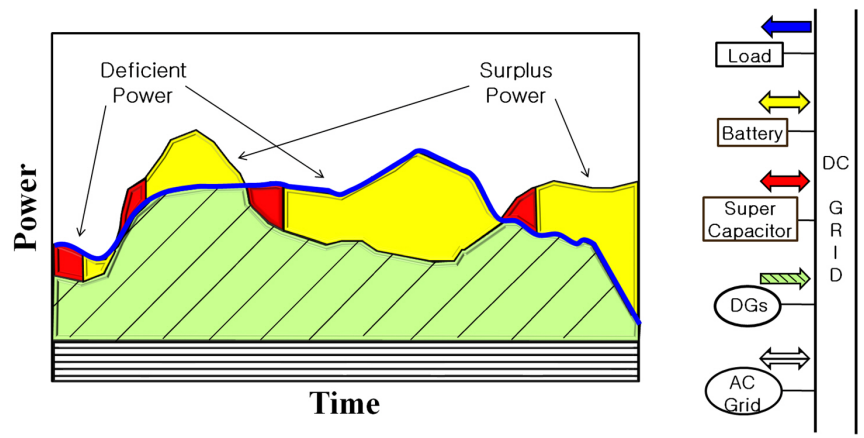

Fig. 3. Operation of grid-tied mode.

\section{B. Power Management Method}

The power management method is analyzed in the both gridtied mode and in the islanded mode. A grid-tied converter has control over the DC grid voltage in the grid-tied mode and energy storage elements have control in the islanded mode. A super-capacitor and a battery ensure a high quality power supply to the load in both modes [11].

Fig. 3 illustrates the concept of the power management method in the grid-tied mode and the bolded curve represents a load demand curve during a day. If the output sum of the DGs is sufficient to charge the storage elements, any excessive power is supplied to ac grid. If the sum of the power of the DGs and the storage elements is deficient with respect to the load demand, the required power is supplied from the ac grid. In the grid-tied mode, power management is performed in a complementary manner between storage elements and as a result the DC micro-grid can operate safely and efficiently.

In the islanded mode, power management is not secured by a super-capacitor because its energy storage capacity is too limited to cover a long-term power supply requirement. However, super-capacitors have a fast charging and discharging capability. Compared with super-capacitors, batteries show a relatively low response but meet the requirements for a long-term power supply. Therefore, super-capacitors undertake sudden and small power changes while batteries undertake the demand for a huge amount of power over a long period of time. In other words, super-capacitors are operative at the moment of transition from charge mode to discharge mode or vice verse. If a super-capacitor reaches its full capacity, the supercapacitor converter stops and the battery converter takes over the charge/discharge operation, i.e. power management.

Fig. 4 illustrates the concept of the power management method in the islanded mode. When a DC micro-grid must be separated from the ac grid and switch to the islanded mode, 

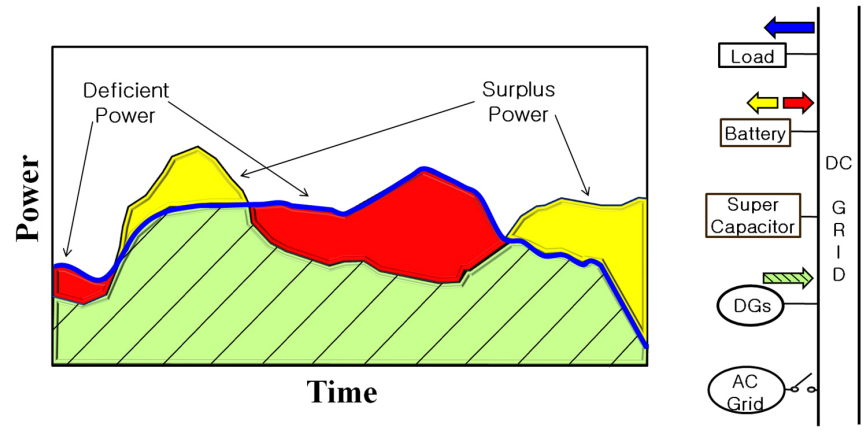

Fig. 4. Operation of islanded operation.

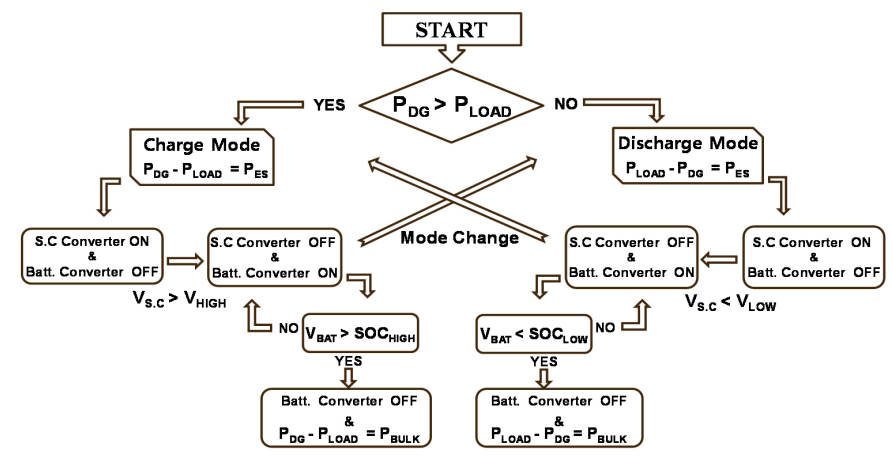

Fig. 5. Flowchart in the grid-tied mode.

the grid-tied converter released control of the DC grid voltage and one of the converters in the micro-grid must take over that control. Since each converter of DGs is used for optimal control of each source, only the converters of the energy storage elements are free to regulate the DC grid voltage. During the islanded mode, the battery plays a main role in regulating the DC grid voltage and the super-capacitor plays a secondary role in responding to the sudden power requirement as an auxiliary converter. In other words, the super-capacitor regulates the DC grid voltage at the moment of the charging - discharging transition and makes up a lack of power which the battery cannot handle. Therefore, the power capability of the super-capacitor can be reduced significantly in the islanded mode.

\section{Control of an Energy Storage Element}

Fig. 5 shows the control method of the energy storage elements during the grid-tied mode. The energy storage elements can transfer between charge and discharge mode in order to maintain the DC grid power balance. If the energy storage elements reach their capacity limitation, they keep the DC grid power balanced by exchanging power from the $\mathrm{AC}$ grid.

As mentioned previously, $\mathrm{P}_{\mathrm{DG}}$ is defined as the total sum of the output from the DGs and the energy storage elements while charging - discharging the difference between $P_{D G}$ and $\mathrm{P}_{\text {LOAD }}$.

If $\mathrm{P}_{\mathrm{DG}}$ is larger than $\mathrm{P}_{\mathrm{LOAD}}$, the difference is charged to the storage elements. In the beginning of the charging interval, the super-capacitor converter starts to charge and if the super-capacitor voltage reaches to the maximum voltage set-value, the converter stops charging. Then battery converter takes over the control of power management and starts to charge the difference. When the battery is completely charged,

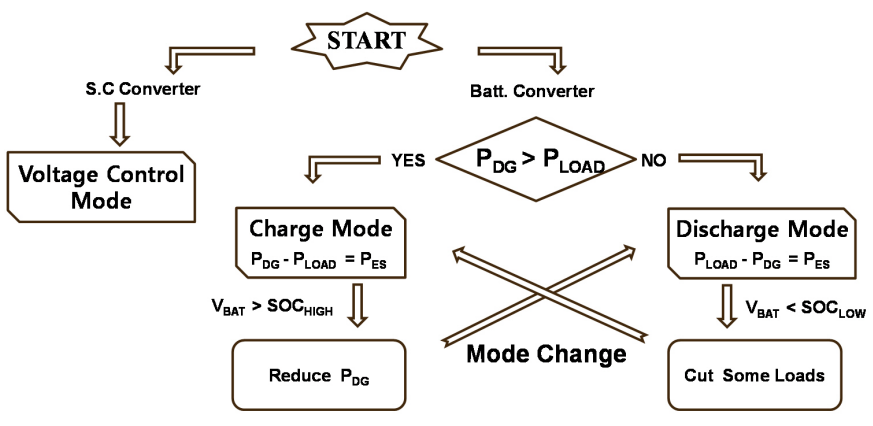

Fig. 6. Flowchart in the islanded mode.

the battery converter stops charging, and the surplus power generated from this moment is transferred to the $\mathrm{AC}$ grid. If $P_{D G}$ is smaller than $P_{L O A D}$, the discharge interval starts, and the difference is discharged from the storage elements. Like the charging interval, the super-capacitor converter starts to discharge at the beginning, and it stops discharging when the super-capacitor voltage reaches its minimum voltage setvalue. After that, the battery converter start to discharge and the converter stops when the battery is discharged completely. Deficient power demanded from this moment is supplied from the AC grid.

Fig. 6 shows the control method for the energy storage elements during islanded mode. During the islanded mode, both the super-capacitor and the battery converter operate continuously. The super-capacitor keeps the DC grid voltage constant even under an abrupt power changes since an auxiliary element and a battery perform power management as a main element.

The battery converter operates with an algorithm similar to the one used in the grid-tied mode. If battery charges up to its maximum soc set-value, the outputs of the DGs are limited and clamped to the load demand. If the battery discharges down to its minimum soc set-value, non-critical loads are disconnected from the DC micro-grid so that the available output of the DGs keeps supplying power to the critical loads.

\section{Operative Analysis for Energy Storage Elements}

Energy storage elements must operate within a range of voltage and soc set-values during the both grid-tied and islanded modes in order to protect and ensure the life time of the elements. Because a battery has an internal resistance and capacitance, the actual voltage can not be measured directly. Normally, to obtain the actual voltage of a battery, the soc is used. The actual voltage in Fig. 7(a) represents a voltage and soc limiting control in the grid-tied mode, where the set voltage ranges of the super-capacitor and the battery are different and should be adjusted in terms of installed capacity. If the voltage of the energy storage elements decreases (increases) to its minimum (maximum) set-value when discharging (charging), the element converter stops switching and prevents the exceeding of its set-values. In Fig. 7(a), $\mathrm{V}_{\text {MAX }}$ is its maximum limiting voltage in charging and $\mathrm{V}_{\mathrm{MIN}}$ is the minimum limiting voltage in discharging. In practical implementation, $\mathrm{V}_{\mathrm{HIGH}}$ and $\mathrm{V}_{\text {LOW }}$ are used to give a greater margin than $\mathrm{V}_{\mathrm{MAX}}$ and $\mathrm{V}_{\text {MIN }}$. Energy storage elements have different limiting set-values in the grid-tied and islanded modes. During the grid-tied mode, 

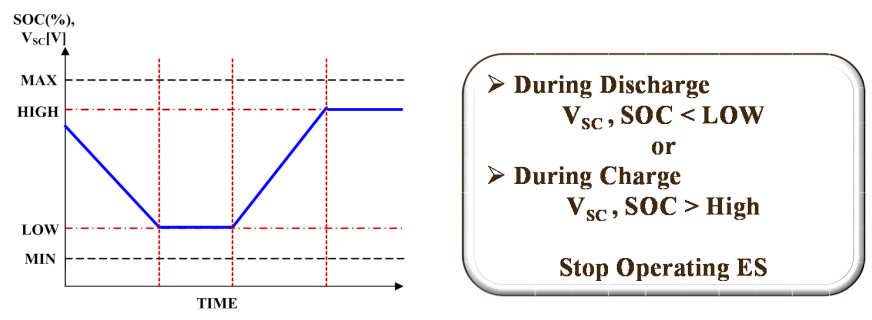

(a)

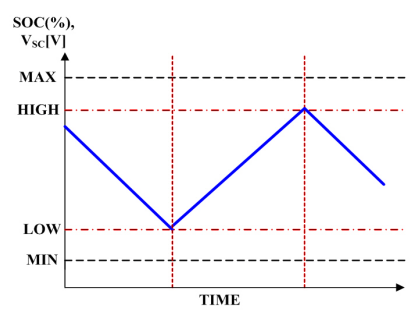

$>$ During Discharge or Charge Keep Operating ES

(b)

Fig. 7. Voltage limit during (a) grid-tied mode, (b) islanded mode.

smaller limiting voltage set-values are used than in the islanded mode so that the energy storage elements must store enough energy to supply the secured power with a load whenever the islanded mode occurs.

Fig. 7(b) represents a voltage limiting control in the islanded mode, where the energy storage elements never stop. If the super-capacitor charges up to its maximum limiting set-value, the super-capacitor converter turns to discharge the power to the dc-grid and the power is charged into battery. On the contrary, if the super-capacitor discharges down to its minimum set-value, the super-capacitor converter turns to charge the power from the dc-grid and the power is discharged from the battery.

In a situation where the output power of DGs is very low, the capacity of the energy storage elements is determined enough to cover the whole load. If $\mathrm{V}_{\text {MIN }}$ is assumed to be $50 \%$ of the rated voltage, the entire energy can be used as shown in (4).

If the required energy and the initial voltage before discharge is already determined, the capacitance of the supercapacitor can be obtained. If the required energy to compensate for $2 \mathrm{~kW}$ for five seconds is $14.7 \mathrm{KJ}$ and the super-capacitor is charged at $160 \mathrm{~V}$ of maximum limiting voltage, the capacitance of the super-capacitor is calculated as (5). The battery capacity is set to $5 \mathrm{~kW}$ according to the grid-tied converter capacity connected to the AC grid. Since the dc-grid voltage is set to $400 \mathrm{~V}$, the minimum limiting set-value of the battery is chosen by considering the possible range of duty of the converter and $100 \mathrm{EA}$ of $1.2 \mathrm{~V}$ unit cell are connected in series. The battery current is calculated as (6).

$$
\begin{gathered}
E_{C}=\frac{1}{2} C V_{1}^{2}-\frac{1}{2} C V_{2}^{2}=\frac{1}{2} C\left(V_{1}^{2}-V_{2}^{2}\right) \\
=\frac{1}{2} C\left(V_{1}^{2}-\left(\frac{1}{2} V_{1}\right)^{2}\right)=\frac{3}{8} C V_{1}^{2}[V] \\
C=\frac{8}{3} \times \frac{E_{C}}{V_{1}^{2}}=\frac{8}{3} \times \frac{14700}{160^{2}}=1.53[F] \\
I_{B}=\frac{P}{V_{B A T} \times \eta}=\frac{5,000 \mathrm{~W}}{120 \mathrm{~V} \times 0.95}=43.9[A] .
\end{gathered}
$$

\section{E. Control of a DC Micro-Grid}

Fig. 8 shows a control block diagram of the components in the proposed DC micro-grid. The grid-tied three-phase converter maintains the dc-grid voltage by an outer voltage loop and an inner current loop. The photovoltaic converter operates at the maximum power point which is a nonlinear function of irradiation and temperature, and the perturbation \& observation technique is employed for the MPPT method since it is stable and easily implemented. The wind power generation also runs with the MPPT method, where maximum power is achieved by keeping the power coefficient of the blade at its maximum value regardless of variations in wind-speed. The wind power converter controller consists of an outer speed loop and an inner current loop.

Since the output voltage of fuel cells has $1: 2$ ratio of the variation between the rated-load and no-load, the fuel cell converter needs high voltage step-up capability. The fuel cell converter controller consists of a current controller and a current command generator, which calculate the reference current by dividing the power command by the fuel cell output voltage.

Fig. 9(a) shows a control block diagram of the battery and the super capacitor converter during the grid-tied mode. The reference power is the difference between the total power generated from the DGs and the load demand. The reference current is calculated by dividing the reference power by the output voltage of the storage element. Then the reference current for each converter leg is calculated by halving the reference current. Each PI controller processes the errors between the reference current and the feedback current of each leg, and then generates PWM gate pulses through the comparator.

Fig. 9(b) shows a control block diagram of the super capacitor converter during the islanded mode. The outer voltage controller calculates the reference current by processing the error between the reference voltage and the feedback dc-grid voltage, and then the same structure is used for the inner current controller.

\section{Detailed Modeling of DGs}

A model of DGs based on PSCAD/EMTDC is developed for a more realistic analytical verification. The generations are implemented by the built-in model and the controller is modeled by a user-defined model coded in C-language. The photovoltaic cell and fuel cell models are implemented by using their characteristic equations. However, the wind generator is implemented by modifying the built-in model of a synchronous generator.

\section{A. PV Array Model}

A solar cell module consists of the (number of serial connection $) \times$ (number of parallel connection) of a solar cell and the output current of a solar cell module is expressed in (7).

The short circuit current is a function of the irradiation and the temperature of a solar cell and is expressed in (8). 


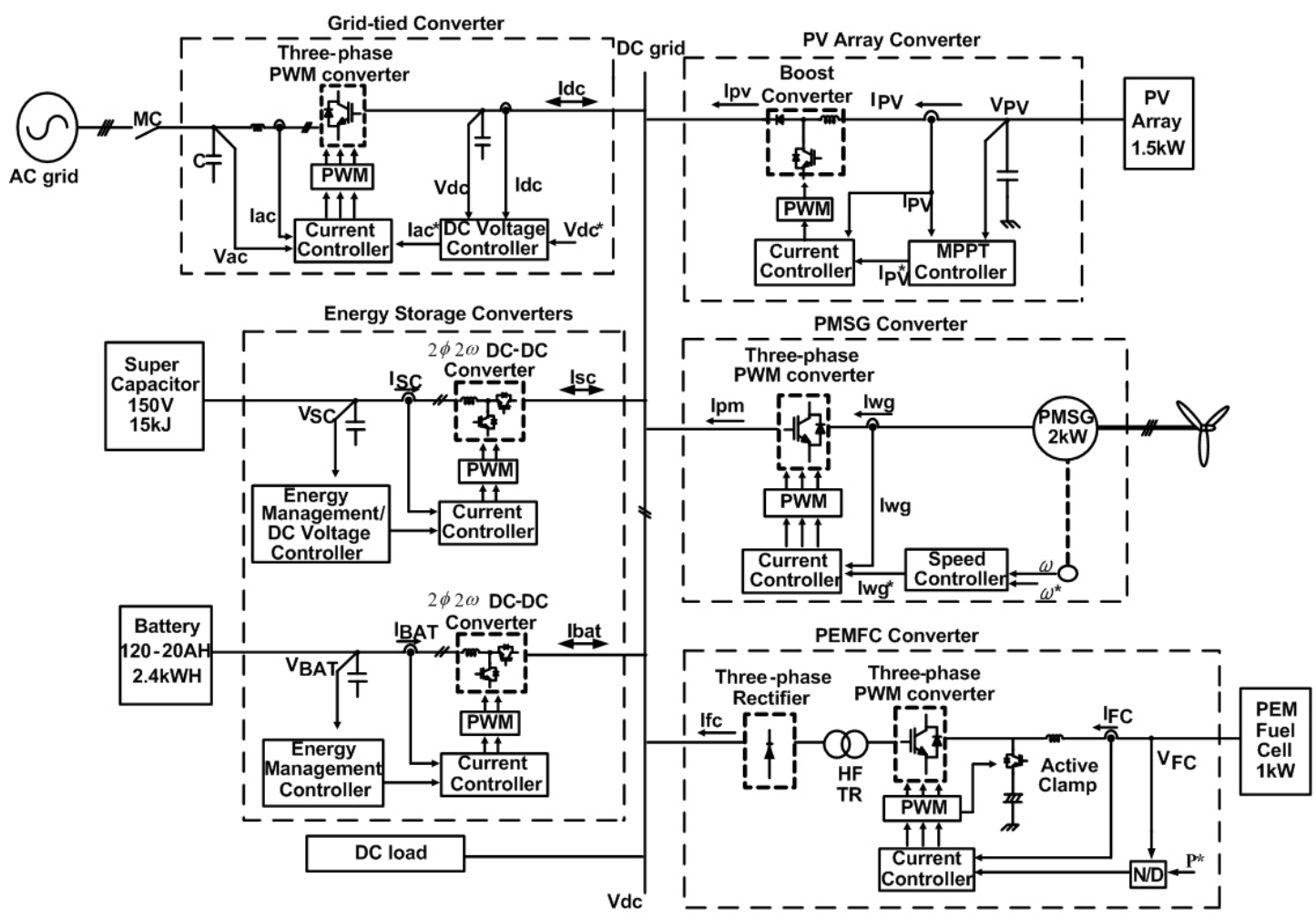

Fig. 8. Control concept of DC micro-grid.

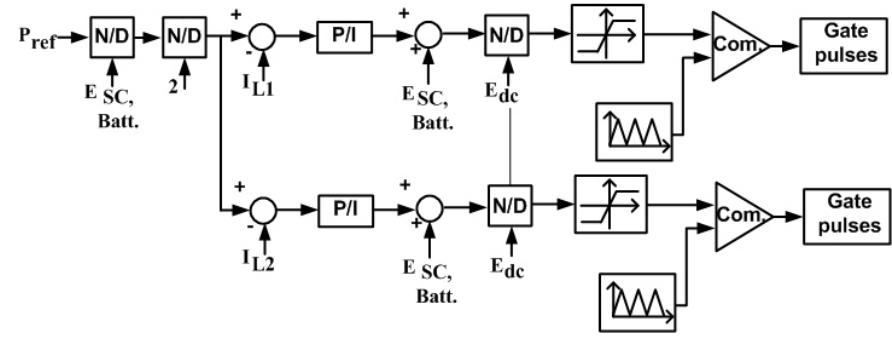

(a)

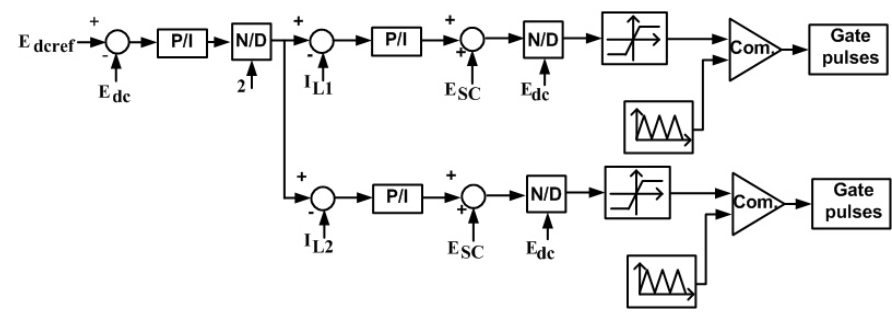

(b)

Fig. 9. Control block diagram in (a) grid-tied and, (b) islanded mode

$$
\begin{gathered}
I_{A}=N_{P} I_{S C}-N_{P} I_{O}\left\{e^{\frac{q\left(V+I R_{S}\right)}{A k_{B} T}}-1\right\}-N_{P}\left(\frac{V+I R_{S}}{R_{S h}}\right)[A] \\
I_{S C}=I_{S C O}\left(\frac{S}{1000}\right)+J\left(T-T_{R E F}\right)[A]
\end{gathered}
$$

where, $T_{R E F}=$ base temperature $(=298[k]), I_{S C O}=$ short circuit current at the base temperature $[A]$ and $S=$ solar irradiation quantity $\left[\mathrm{W} / \mathrm{m}^{2}\right]$. Since the generated power of a solar cell changes mainly in terms of solar irradiation and temperature, the V-I (voltage-current) curve also changes according to the environment conditions. Fig. 10 (a) illustrates the solar cell model implemented in PSCAD/EMTDC. Fig. 10(b) shows the V-I and V-P curves calculated from the implemented solar cell model under the $1000\left[\mathrm{~W} / \mathrm{m}^{2}\right], 25\left[{ }^{\circ} \mathrm{C}\right]$ condition and it shows that the model is implemented accurately.

\section{B. Proton Exchange Membrane Fuel Cell (PEMFC) Model}

The ideal voltage of a unit fuel cell is $1.229 \mathrm{~V}$ but the actual fuel cell voltage is reduced due to the nonlinear characteristic of the three polarization phenomenon. The output voltage of a unit fuel cell is expressed in (9) [8].

where $E_{r, P, T}$ : equilibrium potential voltage, $E_{a c t}$ : activation polarization loss, $\mathrm{E}_{\mathrm{con}}$ : concentration polarization loss and $\mathrm{E}_{\mathrm{ohm}}$ : resistance polarization loss. $\mathrm{E}_{\mathrm{act}}$ is a polarization caused by the differences of the reaction speed on the electrode surface and is expressed in (10). $\mathrm{E}_{\mathrm{con}}$ is a polarization due to the gradient difference of the reactant density as shown in (11). $\mathrm{E}_{\mathrm{ohm}}$ is a polarization caused by the electrolyte resistance, electrode resistance and conductor resistance in (12). The model of a fuel cell is coded in C-language to adopt formulas (10)-(12) and the model is verified by simulation.

$$
\begin{gathered}
E_{\text {cell }}=E_{r, T, P}-E_{\text {act }}-E_{\text {con }}-E_{\text {ohm }}[V] \\
E_{\text {act }}=\frac{R T}{\alpha F} \ln \left(\frac{i+i_{\text {loss }}}{i_{o}}\right)[V] \\
E_{\text {con }}=\frac{R T}{n F} \ln \left(\frac{i_{L}}{i_{L}-i}\right)[V] \\
E_{\text {ohm }}=i R_{i}[V] .
\end{gathered}
$$




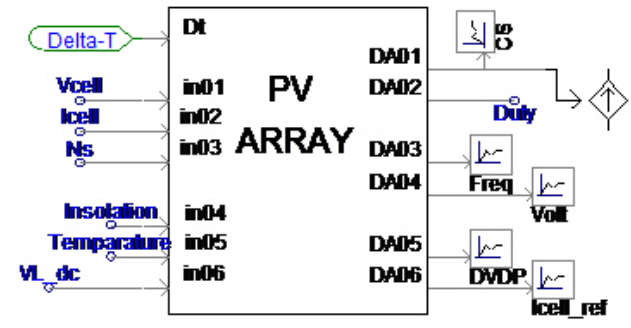

(a)

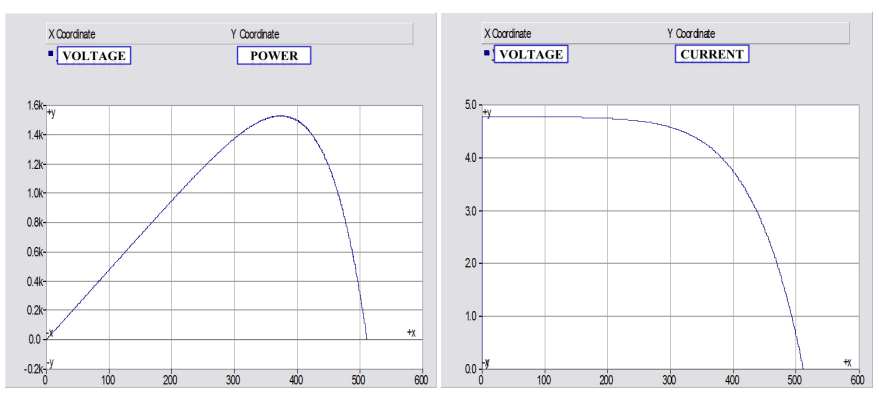

(b)

Fig. 10. Model of PV Array. (a) Model. (b) V-I \& V-P curves.

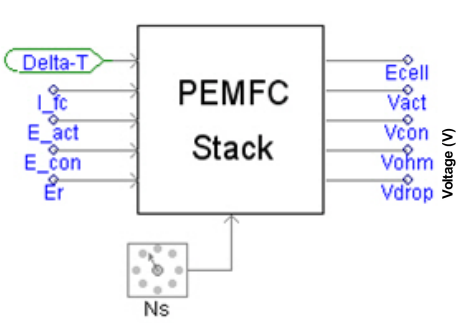

(a)

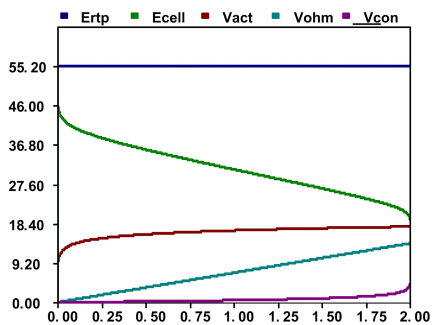

(b)
Fig. 11. Model of fuel cell. (a) Model. (b) Characteristic curves.

Fig. 11 shows the model of a fuel cell and the output voltage characteristic of a fuel cell stack that is composed of 47 cells connected in series. The y-axis shows the actual output voltage, while the $\mathrm{x}$-axis shows the fuel cell current. This curve is required to design the DC-DC converter for a fuel cell power conditioning system. The fuel cell voltage under the no load condition is about $50 \mathrm{~V}$, but it is about $28 \mathrm{~V}$ under the full load condition.

\section{PMSG Model}

Since PSCAD/EMTDC does not provide a PMSG (permanent magnet synchronous generator) library, a PMSM model is developed by applying a constant flux to a built-in wound rotor synchronous machine library. Fig. 12 shows a flowchart of the algorithm which produces blade torque from wind speed. At first, the rotation speed of a PMSG is scaled to the rotation speed of the blade, and the tip speed ratio (TSR) is calculated from the speed and radius of the blade. Then, the power coefficient is calculated by a third order polynomial equation of the TSR and finally, the torque of a $2 \mathrm{~kW}$ PMSG is calculated from the blade power and torque.

Fig. 13 illustrates an implemented model of the PMSG and wind turbine, along with the resulting torque, power and rotation speed of the PMSG. The simulation results show that

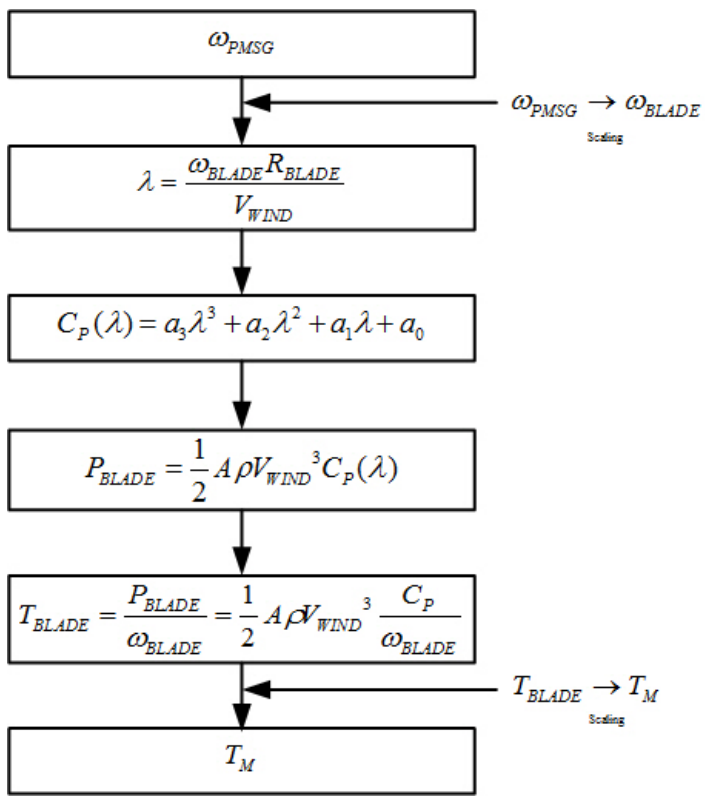

Fig. 12. Algorithm of blade torque calculation.

TABLE I

Parameters for Model of Distributed Generations

\begin{tabular}{|c|c|c|c|c|c|c|}
\hline DG & \multicolumn{6}{|c|}{ Parameters } \\
\hline \multirow{2}{*}{$\mathrm{PV}$} & $\mathrm{N}_{\mathrm{P}}$ & $\mathrm{N}_{\mathrm{S}}$ & $\mathrm{I}_{\mathrm{SC}}[\mathrm{A}]$ & $\begin{array}{c}\mathrm{V}_{\mathrm{OC}} \\
{[\mathrm{V}]}\end{array}$ & $\mathrm{R}_{\mathrm{S}}[\Omega]$ & $\mathrm{R}_{\mathrm{SH}}[\Omega]$ \\
\cline { 2 - 7 } & 1 & 48 & 4.75 & 380 & 0.01 & 1.4 \\
\hline \multirow{2}{*}{$\mathrm{FC}$} & $\mathrm{E}_{\mathrm{r}, \mathrm{T}, \mathrm{P}}$ & $\mathrm{N}_{\mathrm{S}}$ & $\begin{array}{c}\mathrm{F} \\
{[\mathrm{C} / \mathrm{mol}]}\end{array}$ & $\mathrm{T}[\mathrm{K}]$ & $\begin{array}{c}\mathrm{R} \\
{\left[\mathrm{Jmol}^{-1} \mathrm{k}^{-1}\right]}\end{array}$ & $\begin{array}{c}\mathrm{N} \\
{\left[\mathrm{mols}^{-1}\right]}\end{array}$ \\
\cline { 2 - 7 } & 1.12 & 46 & 96485 & 333 & 8.314 & 2 \\
\hline & $\mathrm{R}[\mathrm{m}]$ & $\mathrm{A}\left[\mathrm{m}^{2}\right]$ & $\begin{array}{c}\text { Air } \\
\text { Density } \\
{\left[\mathrm{kg} / \mathrm{m}^{3}\right]}\end{array}$ & $\begin{array}{c}\mathrm{C}_{\mathrm{p}}, \\
\max \\
\text { PMSG }\end{array}$ & $\begin{array}{c}\text { Fre- } \\
\text { quency } \\
{[\mathrm{Hz}]}\end{array}$ & $\begin{array}{c}\text { Rated } \\
\text { Veloc- } \\
\text { ity } \\
{[\mathrm{m} / \mathrm{s}]}\end{array}$ \\
\cline { 2 - 8 } & 34 & 3,629 & 1.225 & 0.468 & 60 & 1200 \\
\hline
\end{tabular}

the PMSG generates a varying power which is proportional to a varying wind speed.

The values of all the parameters for the equations of distributed generation are described in Table I.

\section{Nickel-Metal-Hydride (Ni-MH) Battery Model}

The battery model using only the soc as a state variable is chosen in order to accurately reproduce the manufacturer's curves for a Ni-MH battery. This model assumes the same characteristics for the charge and discharge cycles. The open voltage source is calculated with a non-linear equation based on the actual soc of the battery. The battery voltage is described by equation (13).

The proposed model represents a non-linear voltage which depends on the actual battery voltage. This means that when the battery is almost completely discharged and no current is flowing, the voltage will be nearly zero. This model yields accurate results and also represents the behavior of the battery. The model's parameters are deduced from the discharge characteristics and are assumed to be the same for charging.

The three necessary points used to extract the model parameters are the fully charged voltage, the end of the exponential zone and the end of the nominal zone. The other parameters needed for the output voltage are described by equations (14)(15). The state of charge of the battery can be calculated by equation (16). 


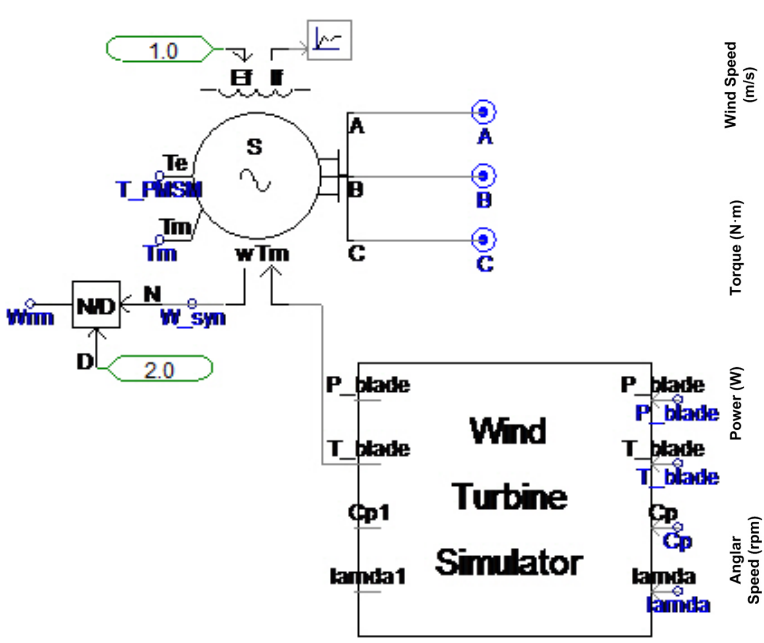

(a)

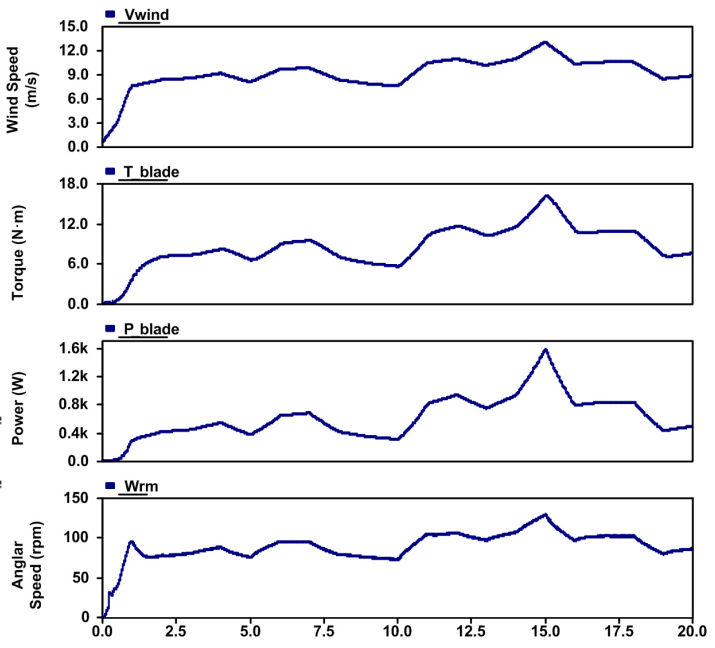

(b)

Fig. 13. Model of PMSG. (a) Model. (b) Characteristic curves.

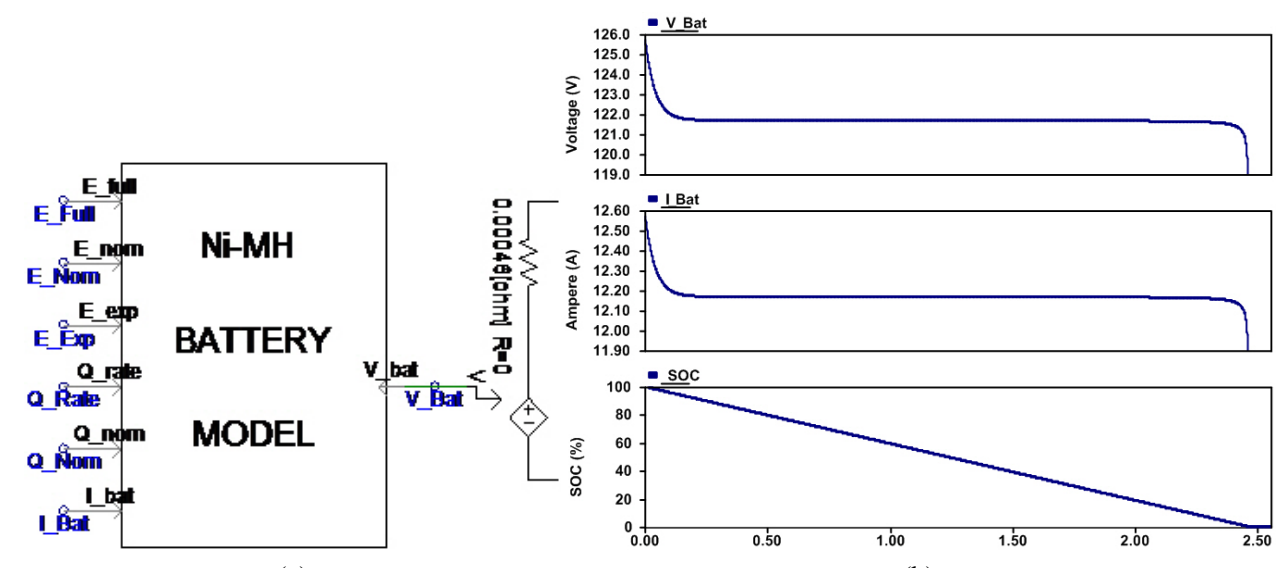

(a)

(b)

Fig. 14. Model of Ni-MH Battery. (a) Model. (b) Characteristic curves.

\section{Simulation Results}

$E=E_{o}-K \frac{Q}{Q-i t}+A \cdot \exp \left(-B \cdot \int_{0}^{t} i d t\right)-R \cdot i[V]$

$K=\frac{\left(E_{F u l l}-E_{\text {Nom }}+A\left(\exp \left(-B \cdot Q_{\text {Nom }}\right)-1\right)\right) \cdot\left(Q-Q_{\text {Nom }}\right)}{Q_{\text {Nom }}}[V]$

$$
\begin{gathered}
E_{o}=E_{F u l l}+K+R i-A[V] \\
S O C=100\left[1-\left(\int i d t\right) / Q\right][\%] .
\end{gathered}
$$

The Ni-MH battery is modeled using a controlled voltage source with a constant resistance. Fig. 14 shows a model of the battery and the output characteristics of the battery.

Considering the duration of the simulation time, the battery capacity is set to ampere-seconds. In the results, the battery capacity is set to 30 ampere-seconds and the nominal output voltage is set to 121 volts.

\section{A. Simulation Scenario}

In order to verify the proposed power management method for a DC micro-grid, simulations are accomplished in the PSCAD/EMTDC environment, where the built-in library of PSCAD/EMTDC is used for the power components and the PWM generating circuit. However, the models of the DGs and their relevant controllers are implemented by a user-defined model coded in C language. The proposed DC micro-grid is simulated in the both the grid-tied and islanded modes for 7 seconds that are scaled from one-day and the scenario methodology is adopted to verify the proposed power management method.

The operating mode in the simulation is scheduled in terms of the interval of the grid-tied mode, the islanded mode, and varying the load demand and time as listed in Table II.

A smooth change in the load demand is easily implemented by controlling the increment of the step change. In order to emulate the substantial output characteristics of DGs, the environmental data are changed in the time base, which results 
TABLE II

OPERATION SCENARIO

\begin{tabular}{|l|c|c|c|c|c|c|c|}
\hline TIME(sec) & $\sim 0.4$ & $\sim 1.0$ & $\sim 1.5$ & $\sim 2.0$ & $\sim 3.0$ & $\sim 4.5$ & $\sim 7.0$ \\
\hline Islanded Mode & & & & & & & \\
\hline Grid-tied mode & & & & & & & \\
\hline Main Load [W] & 0.0 & 3200 & 0.0 & 3550 & 320 \\
\hline Sub Load [W] & \multicolumn{7}{|c|}{0.0} \\
\hline
\end{tabular}

TABLE III

SCENARIO SITUATION

\begin{tabular}{|c|c|}
\hline Mode & See details \\
\hline \multirow{4}{*}{ Grid-tied Mode } & 1. Mode change while super capacitor is operating \\
\hline & $\begin{array}{l}\text { 2. Operation of battery when super capacitor reaches to } \\
\text { voltage set-value }\end{array}$ \\
\hline & 3. Mode change while battery is operating \\
\hline & $\begin{array}{l}\text { 4. Power flow from AC grid when Battery reaches to } \\
\text { soc set-value }\end{array}$ \\
\hline \multirow{3}{*}{ Islanded Mode } & 1. Turn to islanded mode when islanding occurs \\
\hline & 2. Reduction of power from DGs when battery reaches \\
\hline & $\begin{array}{l}\text { 10 maximum soc } \\
\text { 3. Load-shedding when Battery reaches to minimum } \\
\text { soc }\end{array}$ \\
\hline
\end{tabular}

in a fluctuating output power. Table III summarizes the details to be checked in the simulation and Table IV summarizes the simulation parameters of the components in the DC microgrid. In order to verify the operation of the energy storage elements for a short simulation time, the operation ranges of the energy storage elements are adjusted.

\section{B. Simulation Result Analysis}

Fig. 15(a) shows the sum of the output power of the DGs. Fig. 15(b) shows the power fluctuation of the PV Array and Fig. 15(c) shows the power fluctuation of the PMSG. The output of wind power and photovoltaic generation vary according to wind speed and irradiation, respectively and their corresponding converters operate with the MPPT method. Fig. 15(d) shows the power of the fuel cell. During the islanded mode, when battery reaches to its maximum soc, the output

TABLE IV

PARAMETER OF COMPONENTS

\begin{tabular}{|c|c|c|c|c|c|}
\hline \multicolumn{6}{|c|}{ Grid-tied Converter } \\
\hline $\mathrm{C}_{\mathrm{DC}}$ & $\mathrm{L}_{\mathrm{F}}$ & $\mathrm{C}_{\mathrm{F}}$ & Transformer & \multicolumn{2}{|c|}{ SwitchingFrequency } \\
\hline $3300[\mathrm{uF}]$ & $3[\mathrm{mH}]$ & $10[\mathrm{uF}]$ & $\begin{array}{c}\mathrm{Y}-\mathrm{Y}, \\
380: 220\end{array}$ & \multicolumn{2}{|c|}{$10[\mathrm{kHz}]$} \\
\hline \multicolumn{6}{|c|}{ PMSG \& Converter } \\
\hline $\begin{array}{l}\text { Rated } \\
\text { Power }\end{array}$ & $\begin{array}{c}\text { Rated } \\
\text { Voltage }\end{array}$ & $\begin{array}{c}\text { Rated } \\
\text { Velocity }\end{array}$ & $\begin{array}{c}\text { Rated } \\
\text { Frequency }\end{array}$ & Inertia & $\begin{array}{l}\text { Switching } \\
\text { Frequency }\end{array}$ \\
\hline $2[\mathrm{~kW}]$ & $220[\mathrm{~V}]$ & $1200[\mathrm{rpm}]$ & $60[\mathrm{~Hz}]$ & $\begin{array}{c}0.01 \\
{\left[\mathrm{~kg} \cdot \mathrm{m}^{2}\right]}\end{array}$ & $10[\mathrm{kHz}]$ \\
\hline \multicolumn{6}{|c|}{ PV Array \& Converter } \\
\hline $\begin{array}{l}\text { Rated } \\
\text { Power }\end{array}$ & $\mathrm{V}_{\mathrm{OC}}$ & $\mathrm{I}_{\mathrm{SC}}$ & $\mathrm{C}_{\mathrm{PV}}$ & $\mathrm{L}_{\mathrm{PV}}$ & $\begin{array}{l}\text { Switching } \\
\text { Frequency }\end{array}$ \\
\hline $1.5[\mathrm{~kW}]$ & $440[\mathrm{~V}]$ & $4.75[\mathrm{~A}]$ & $270[\mathrm{uF}]$ & $2[\mathrm{mH}]$ & $20[\mathrm{kHz}]$ \\
\hline \multicolumn{6}{|c|}{ PEMFC \& Converter } \\
\hline $\begin{array}{l}\text { Rated } \\
\text { Power }\end{array}$ & $\begin{array}{c}\text { Rated } \\
\text { Voltage }\end{array}$ & HF Tr. & $\mathrm{C}_{\mathrm{FC}}$ & $\mathrm{L}_{\mathrm{FC}}$ & $\begin{array}{l}\text { Switching } \\
\text { Frequency }\end{array}$ \\
\hline $1[\mathrm{~kW}]$ & $43[\mathrm{~V}]$ & $1: 4$ & $240[\mathrm{uF}]$ & $3[\mathrm{mH}]$ & $80[\mathrm{kHz}]$ \\
\hline \multicolumn{6}{|c|}{ Super Capacitor \& Converter } \\
\hline Capacitance & $\begin{array}{l}\text { Internal } \\
\text { Resis- } \\
\text { tance }\end{array}$ & $\mathrm{L}_{\mathrm{SC}}$ & $\mathrm{V}_{\mathrm{HIGH}}$ & $\mathrm{V}_{\text {LOW }}$ & $\begin{array}{l}\text { Switching } \\
\text { Frequency }\end{array}$ \\
\hline $1.6[\mathrm{~F}]$ & $0.1[\Omega]$ & $2[\mathrm{mH}]$ & $105[\mathrm{~V}]$ & $95[\mathrm{~V}]$ & $20[\mathrm{kHz}]$ \\
\hline \multicolumn{6}{|c|}{ Battery \& Converter } \\
\hline $\begin{array}{l}\text { Rated } \\
\text { Voltage }\end{array}$ & $\begin{array}{l}\text { Internal } \\
\text { Resis- } \\
\text { tance }\end{array}$ & $\mathrm{L}_{\mathrm{BAT}}$ & $\mathrm{SOC}_{\mathrm{HIGH}}$ & $\mathrm{SOC}_{\mathrm{LOW}}$ & $\begin{array}{l}\text { Switching } \\
\text { Frequency }\end{array}$ \\
\hline $120[\mathrm{~V}]$ & $4.6[\mathrm{~m} \Omega]$ & $2[\mathrm{mH}]$ & $95[\%]$ & $50[\%]$ & $20[\mathrm{kHz}]$ \\
\hline
\end{tabular}

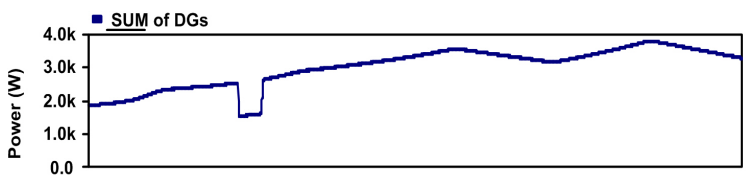

(a)

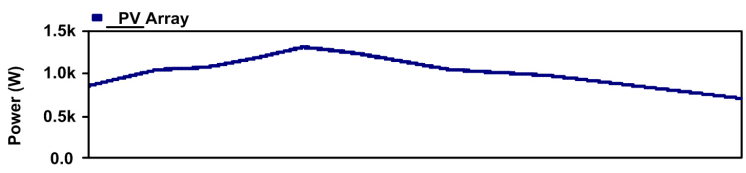

(b)

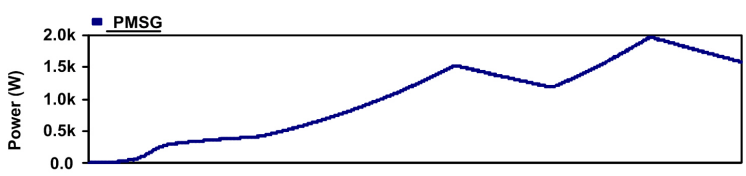

(c)

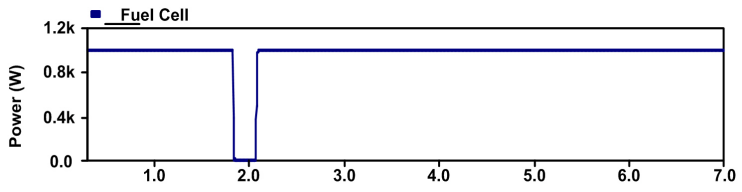

(d)

Fig. 15. Power of DGs. (a) PV Array. (b) Fuel cell. (c) PMSG. (d) Sum of DGs.

of the fuel cell is controlled to zero. Fig. 16(a) is the sum of the load demand, Fig. 16(b) is the demand of the main load and Fig. 16(c) is the demand of sub load. It can be confirmed that the main load is supplied as much power as it demands durring the entire simulation time. During the islanded mode, when the battery reaches its minimum soc, the non-critical load is disconnected as shown Fig. 16(b). Fig. 16(d) shows the powers handled by the battery and super-capacitor in the same graph for comparison. Fig. 16(e) is the power of the AC grid. During the grid-tied mode, when the battery reaches its soc set-value, the surplus power is supplied to the AC grid or the deficient power is supplied power from the AC grid.

Fig. 17(a) shows the voltage of the super-capacitor that is operated with the range of voltage set-value. Fig. 17(b) shows the battery voltage and Fig. 17(c) shows the soc of the battery that is operated with the range of the soc set-value. The energy storage converters are operated separately during the grid-tied mode and they are operated simultaneously during the islanded mode.

Fig. 18(a) shows the DC grid voltage that is kept constant during the entire simulation time. Fig. 18(b) shows the AC grid current and Fig. 18(c) represents the THD (total harmonic distortion) of the AC grid current and the THD is less than $5 \%$ even in the transition between two modes.

The simulation analysis proves that the DC micro-grid is able to supply as much high quality power continuously as the load demands, whether the micro-grid is connected to the AC grid or not. In addition, it proves that the micro-grid is able to supply a stable power to the load without a significant disturbance at the instant of transfer between the islanded mode and the grid-tied mode. 


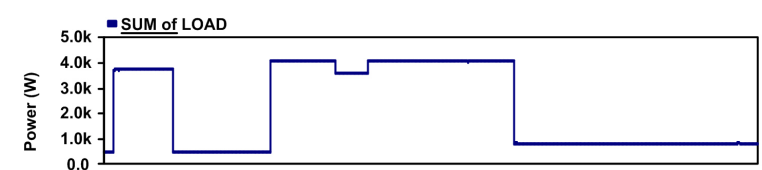

(a)

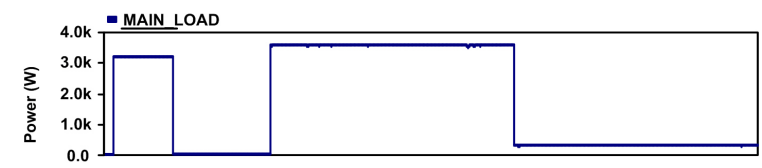

(b)

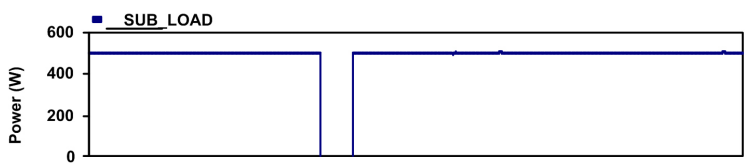

(c)

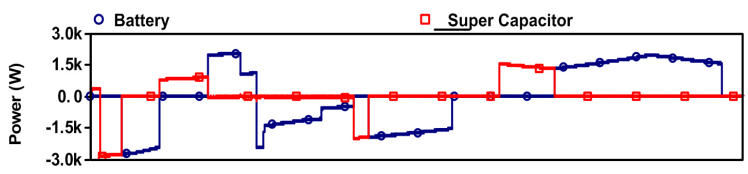

(d)

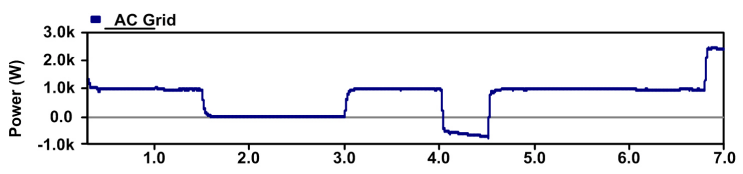

(e)

Fig. 16. Power of elements. (a) Sum of load. (b) Main load. (c) Sub load. (d) Battery and super capacitor. (e) AC grid.

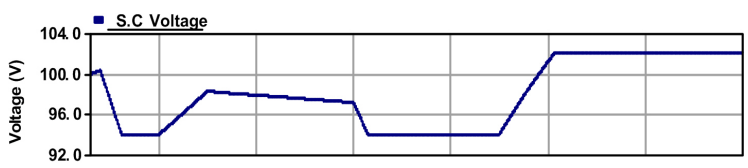

(a)

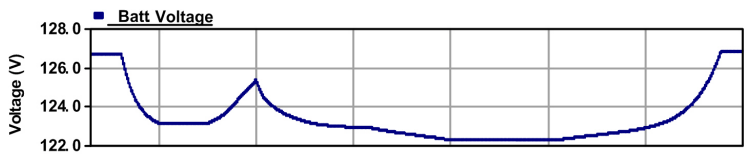

(b)

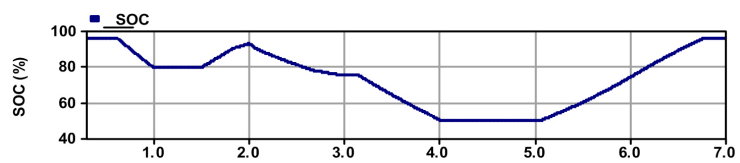

(c)

Fig. 17. Voltage of energy storage elements. (a) Super capacitor voltage. (b) Battery voltage. (c) SOC of battery.

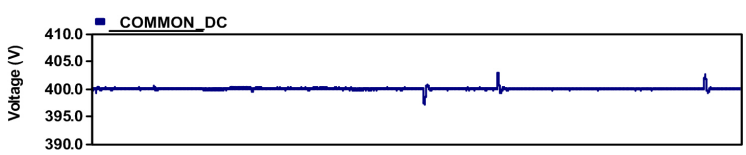

(a)

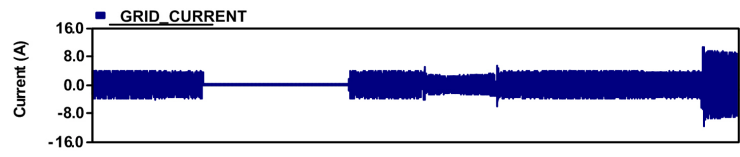

(b)

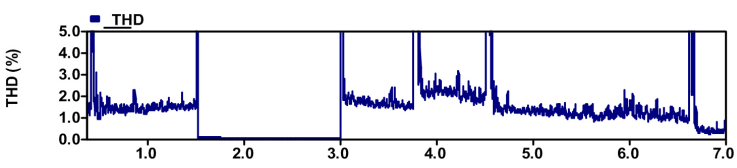

(c)

Fig. 18. AC grid current and DC grid voltage. (a) DC grid voltage. (b) AC grid current. (c) THD of AC grid current.

\section{CONCLUSION}

In this paper, the operating characteristics of DGs have been analyzed and models of DGs together with their relevant controllers have been implemented in PSCAD/EMTDC. A DC micro-grid has been configured by connecting the developed models and a power management method has been proposed for both the grid-tied mode and the islanded mode. Simulation results have verified that the proposed power management method ensures a secure power supply and efficient operation of the proposed DC micro-grid in the both operation modes. The developed DC micro-grid provides a basic research foundation and it can be easily extended to a DC dispatch system and a smart grid. The outcomes can be widely utilized for miniature-scaled hardware implementation or the development of a real scale demonstrative system.

\section{ACKNOWLEDGMENT}

This work was supported by the Energy Efficiency and Resources R\&D Program (2010T100200213) under the Ministry of Knowledge Economy, Republic of Korea.

\section{REFERENCES}

[1] R. H. Lasseter and P. Paigi, "Microgrid : A conceptual solution," in $35^{\text {th }}$ Annual IEEE Power Electronics Specialists Conference, pp. 4285-4290, 2004.

[2] S. Papathanassiou, D. Georgakis, N. hatziaqyriou, A. Engler, and C. Hardt, "Operation of a prototype Micro-grid system based on microsources equipped with fast-acting power electronics interfaces," IEEE PESC 2004, Vol.4, pp. 2521-2526, Jun. 2004.

[3] S. Morozumi, "Micro-grid demonstration projects in japan," PCC(Power Conversion Conference) 2007, pp. 635-642, Apr. 2007.

[4] H. Kakigano, Y. Miura, T. Ise, and R. Uchida, "DC micro-grid for super high quality distribution -System configuration and control of distributed generation and energy storage devices-,"' IEEE PESC '06, pp. 1-7, Jun. 2006.

[5] H. Kakigano, Y. Miura, T. Ise, and R. Uchida, "DC voltage control of the DC micro-grid for super high quality distribution," $P C C$ (Power Conversion Conference) 2007, Apr. 2007.

[6] Y. Li, D. Vilathgamuwa, and P. Loh, "Design, analysis, and real-time testing of a controller for multi-bus micro-grid system," IEEE Trans. Power Electron., Vol. 19, No. 5, pp 1195-1204, Sep. 2004. 
[7] H. Lee, J. Jeong, J. Lee, B. Han, N.Choi, H.Cha, "18-step back-toback voltage source converter with pulse interleaving circuit for HVDC application," Journal of Electrical Engineering \& Technology, Vol. 5, No. 3, pp. $435 \sim 442$ Sep. 2010.

[8] J. Lee, J. Jeong, B. Han, N. Choi, H, Cha, "DFIG wind power system with a DDPWM controlled matrix converter," Journal of Electrical Engineering \& Technology, Vol. 5, No. 2, pp. 299 306, Jun. 2010.

[9] J. Jeong, J. Lee, B. Han, H. Cha, "Grid-tied power conditioning system for fuel cell composed of three-phase current-fed DC-DC converter and PWM inverter," Journal of Electrical Engineering \& Technology, Vol. 6, No. 2, pp. $255 \sim 262$, Mar. 2011.

[10] P. Biczel, "Power electronic converters in DC microgrid," IEEE CPE'07 (Compatibility in Power Electronics 2007), pp. 1-6, May/Jun. 2007.

[11] F. Katiraei, R. Iravani, and P. Lehn, "Micro-grid autonomous operation during and subsequent to islanding process," IEEE Trans. Power Del., Vol. 20, No. 1, pp 248-257, Jan. 2005.

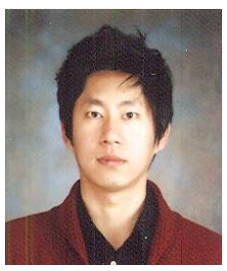

Ji-Heon Lee received his B.S. and M.S. in Electrical Engineering from Myongji University, Korea, in 2008 and 2010 , respectively. He is currently a Ph.D. candidate at Myongji University. His research interests include power electronics applications for custom power systems and distributed generation.

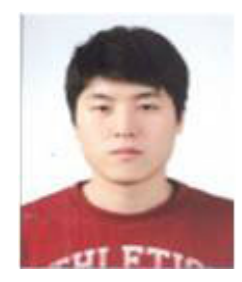

Hyun-Jun Kim received his B.S. in Electrical Engineering from Myongji University, Korea, in 2011. He is currently working toward his M.S. at Myongji University. His research interests include power electronics applications for custom power systems and distributed generation.

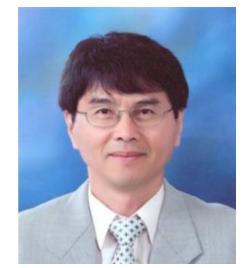

Byung-Moon Han received his B.S. in Electrical Engineering from Seoul National University, Korea, in 1976, and his M.S. and Ph.D. from Arizona State University in 1988 and 1992, respectively. He was with the Westinghouse Electric Corporation as a Senior Research Engineer in the Science and Technology Center. Currently he is a Professor in the Department of Electrical Engineering, Myongji University, Korea. His research interests include power electronics applications for FACTS, custom power, and distributed generation.

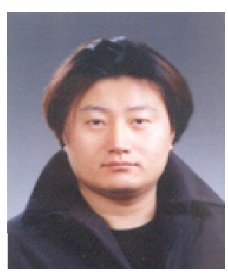

Yu-Seok Jeong was born in Daegu, Korea, in 1971. $\mathrm{He}$ received his B.S., M.S. and Ph.D. degrees from Seoul National University, Seoul, Korea, in 1993, 1995, and 2005, respectively, all in Electrical Engineering. He joined the Kia Motors Technical Center, Seoul, Korea, as a Research Engineer in 1995. In 2001 and 2002, he was a special student at the University of Wisconsin, Madison. During his doctoral course, he pursued faulttolerant control and robust adaptive control of IPM synchronous machine drives in collaboration with GM. Following a one-year experience to develop a motor drive system for HEV/FCV applications at Hyundai Motor Company in 2005, he is currently with the Dept. of Electrical Eng., Myongji Univ., Gyeonggi-do, Korea. His research interests include modeling and digital control of power electronics and energy conversion.

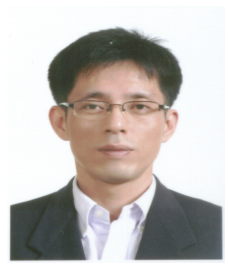

Hyo-Sik Yang is an assistant professor at Sejong University, Department of Computer Science and Engineering, Seoul, Korea. Before he joined Sejong University, he was an assistant professor at Kyungnam University, Masan, Korea. He joined Sejong University on Fall 2006. He was a faculty research associate at Arizona State University (ASU), 2005. He received the B. E. degree in the department of information and communication engineering from Myongji University, Yongin, Korea, in 1998 and the M. S. and Ph. D. in Electrical Engineering from Arizona State University, Tempe, AZ, U.S.A., in 2000 and 2005, respectively. His research interests are wavelength- division-multiplexing (WDM) alloptical networks, WDM packet switching, and WDM metropolitan area

networks including node architecture, optimization, medium access control (MAC), traffic analysis, and routing in mobile ad-hoc networks (MANETs). $\mathrm{He}$ is working on Substation Automation System (SAS) complying with IEC 61850 , Communication networks and system in substations.

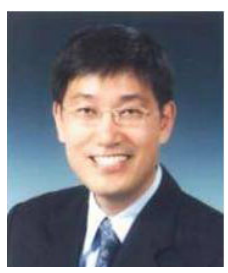

Han-Ju Cha received his B.S. in Electrical Engineering from Seoul National University, Seoul, Korea, his M.S. from the Pohang Institude of Science and Technology, Korea, and his Ph.D. from Texas A\&M University, College Station, TX in 1988, 1990 and 2004, respectively, all in Electrical Engineering. From 1990 to 2001, he was with LG Industrial Systems, Anyang, Korea, where he was engaged in the development of power electronics and adjustable speed drives. In 2005, he joined the Department of Electrical Engineering, Chungnam National University, Daejeon, Korea. He worked as a Visiting Professor in the United Technology Research Center, Hartford CT, USA in 2009. His current research interests include highpower $\mathrm{dc}-\mathrm{dc}$ converters, ac/dc, dc/ac and ac/ac converter topologies, power quality, and utility interface issues for distributed energy systems and microgrids. 